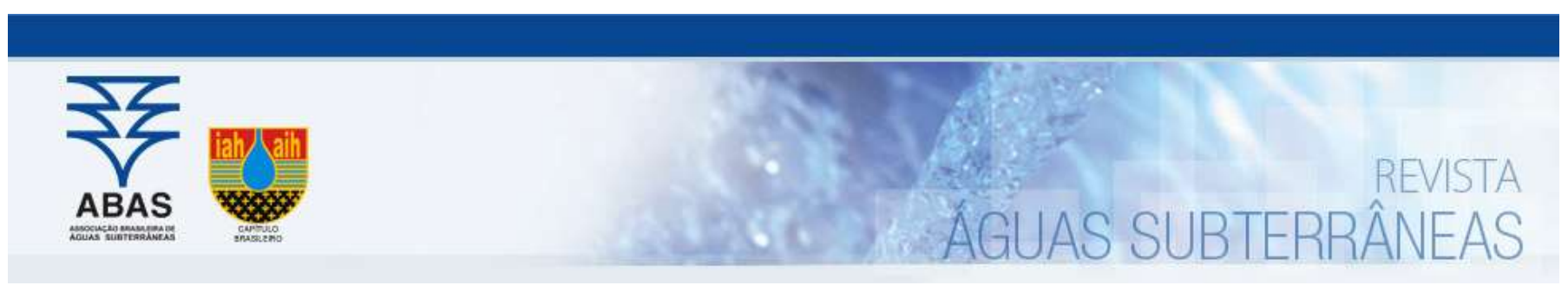

Artigos

\title{
A Comparative Study of Methods for Determining the Concentration of Radon-222 in Spring Waters in Poços de Caldas Plateau, Brazil
}

\section{Estudo Comparativo de Métodos para Determinação da Concentração de Radônio-222 em fontes naturais de águas no Planalto de Poços de Caldas, Brasil}

\author{
Flavio Henrique de Souza Moreira ${ }^{1}$; Heber Luiz Caponi Alberti1; Maria Helena Tirollo Taddei ${ }^{1}$; Nivaldo Carlos Silva ${ }^{1}$; Peter Marshall \\ Fleming $1 \bowtie$
}

${ }^{1}$ Comissão Nacional de Energia Nuclear-CNEN, Rio de Janeiro, RJ

$\bowtie$ flaviohsmoreira2@gmail.com, heber@cnen.gov.br, mhtaddei@cnen.gov.br, ncsilva@cnen.gov.br, pmf@cnen.gov.br Abstract

Spring water.

Radon.

Comparison methodology.
Keywords:

\begin{abstract}
This study is a comparison of methodologies to determine the concentration of radon $\left({ }^{222} \mathrm{Rn}\right)$ found in natural water sources used by the population of the cities of Poços de Caldas and Águas da Prata in the Poços de Caldas Plateau, in southeastern Brazil. The plateau is located in an area affected by the reactivation of volcanic processes that occurred during its formation. This is the largest alkaline complex in Brazil and the greatest stratum-alkaline volcano of Poços de Caldas is a volcanic caldera of about $30 \mathrm{~km}$-diameter, consisting of plutonic igneous rocks, where uranium and thorium anomalies are found. Sampling of spring water was carried out throughout the cities and ${ }^{222} \mathrm{Rn}$ concentration in waters was determined in Becquerel per liter. Radiation levels found in natural sources were interpreted in accordance to the limits for total doses absorbed by an individual and the standards of radiological protection of the World Health Organization (WHO). Determination of the concentration of $222 \mathrm{Rn}$ found in the waters was possible through the capture of alpha particles emitted by the decay of the element, accomplished with the use of the Radon Professional Monitor (AlphaGUARD) and were also measured through the Liquid Scintillation Counting method, equipment brand Camberra PACKARD. The highest value reached was 657.2 Bq.L-1, measured by the AlphaGUARD, and 513.2 Bq.L-1, measured through the liquid scintillation method.
\end{abstract}

Resumo

Palavras-chave:

Água de nascente.

Radônio.

Comparação metodológica.

Revisado por pares.

Recebido em: 20/11/2017.

Aprovado em: 25/02/2018.

\begin{abstract}
Este estudo é uma comparação de métodos para determinar a concentração de radônio (222Rn), que foi realizado em fontes de água natural utilizadas pela população das cidades de Poços de Caldas e Águas da Prata no Planalto de Poços de Caldas, no sudeste do Brasil. 0 planalto está localizado em área afetada pela reativação de processos vulcânicos que ocorreram durante sua formação. Este é o maior complexo alcalino no Brasil e caracterizado por uma caldeira vulcânica de cerca de 30km de diâmetro, constituída por rochas ígneas plutônicas, onde são encontradas anomalias de urânio e tório. As amostragens foram realizadas em fontes naturais de água distribuídas pelas cidades e a concentração de ${ }^{222 R n}$ nas águas foi determinada em Becquerel por litro. Os níveis de radiação encontrados nas fontes naturais foram comparados com os limites das doses totais absorvidas por um indivíduo e os padrões de proteção radiológica estabelecidos pela Organização Mundial de Saúde (OMS). A determinação da concentração de atividade de ${ }^{222} \mathrm{Rn}$ encontrada nas águas foi possível através da captura de partículas alfa emitidas pelo decaimento do elemento, realizadas com o equipamento profissional de monitoramento de radônio (AlphaGUARD) e também pelo do método de contagem de cintilação líquida, utilizando equipamento da marca Camberra PACKARD. Os maiores valores aferidos foram de 657,2 Bq.L-1, medido pelo AlphaGUARD e, 513,2 Bq.L-1, obtido através do método de cintilação líquida.
\end{abstract}

DOI: http://dx.doi.org/10.14295/ras.v32i1.28973

\section{INTRODUCTION}

The natural radioactivity found in natural water originates from dissolved radioactive elements (e.g. uranium), radioactive elements suspended in colloidal form (e.g. thorium), suspended radioactive elements (e.g. microcrystals of radioactive elements) and diffused radioactive elements (e.g. radon). Thus, the natural radioactivity in waters comes mainly from rocks and minerals in which water comes in contact (NIKEZIC \& YU, 2004). Natural wa- ters may be regarded as the main transport agent of radioactive elements under several geophysical and geochemical conditions (BONOTTO \& LIMA,1997).

The gas radon is the most abundant among the elements responsible for radioactivity in waters (BUSHONG, 2001; MAFRA, 2011). The three naturally occurring isotopes radon are the ${ }^{222} \mathrm{Rn}$ with a half-life of 3.82 days, ${ }^{220} \mathrm{Rn}$ with a half-life of 64 seconds and the ${ }^{219} \mathrm{Rn}$ with a half-life of 3.92 seconds and are respectively mem- 
bers of $238 \mathrm{U},{ }^{235} \mathrm{U}$ and ${ }^{232} \mathrm{Th}$ decay chains. ${ }^{222} \mathrm{Rn}$ is the one that best characterizes radioactive waters and is the easiest to be found in nature, as consequence of its fairly long half-life when compared to that of the other isotopes (BURNETT \& DULAIOVA, 2003). ${ }^{222} \mathrm{Rn}$ occurs naturally from the decay of ${ }^{226} \mathrm{Ra}$ and its spreads easily to the environment, being considered one of the natural radioactive elements with greater mobility in the Earth's crust, commonly it is found in waters in contact with rocks with high uranium concentration (DESIDERI et al., 2009).

The concentration of radon in the water is directly related to factors such as the lithology of the zone in contact with the water, the degree of alteration by weathering or hydrothermalism, the surface extension and the contact time between water and rocks. In addition, physical-chemical factors such as pressure, temperature, $\mathrm{pH}$ and oxidation-reduction potential must be considered (IBRAHIMI, 2009; THAKKAR, 2011).

The origin of $222 \mathrm{Rn}$ in the dwellings is strictly related to gaseous emanations by uranium, thorium and radio rich soil and rock or by the use of materials rich in ${ }^{226} \mathrm{Ra}$ in residential constructions, such as uranium mining tailings (BUSHONG, 2001). The main means of ingestion of ${ }^{222} \mathrm{Rn}$ is due to the consumption of groundwater (artesian wells or springs) originating from regions where rocks are associated with radioactive elements. In the Poços de Caldas Plateau in certain regions there are characterized by high natural radioactivity (BONOTTO \& LIMA,1997; DIAS \& TADDEI, 2009; VEIGA, 2003).
Measurements of ${ }^{222} \mathrm{Rn}$ concentration in spring waters from the city of Poços de Caldas - Minas Gerais State / Brazil - and the city of Águas da Prata - São Paulo State / Brazil - was measured with an ionization chamber of a Radon Professional Monitor (AlphaGUARD), on the sample collection site. The second water samples were obtained simultaneously and was used a cocktail that preserves your properties and the gas, which was subsequently analyzed in the laboratory of Poços de Caldas (LAPOC) of the Brazilian Commission for Nuclear Energy (CNEN) through the method of Liquid Scintillation Counting (LSC), equipment brand Camberra PACKARD. The determination of the radon concentration can provide information on the water quality of springs used by the population, as well as a classification of the springs in relation to the admissible indices. Furthermore, this study aims to compare the analytical methods of $222 \mathrm{Rn}$ measurement.

\section{EXPERIMENTAL}

\subsection{Sampling}

Figure-1 shows the sampling locations, all samples are of waters from springs, the sites are located in the urban area of the Poços de Caldas city, totaling thirteen samples, and also in the urban area of the Águas da Prata city, totaling two samples. The sampling campaign was conducted in 2014 . The samples were obtained in sources that continuously provide drinking water for the population.

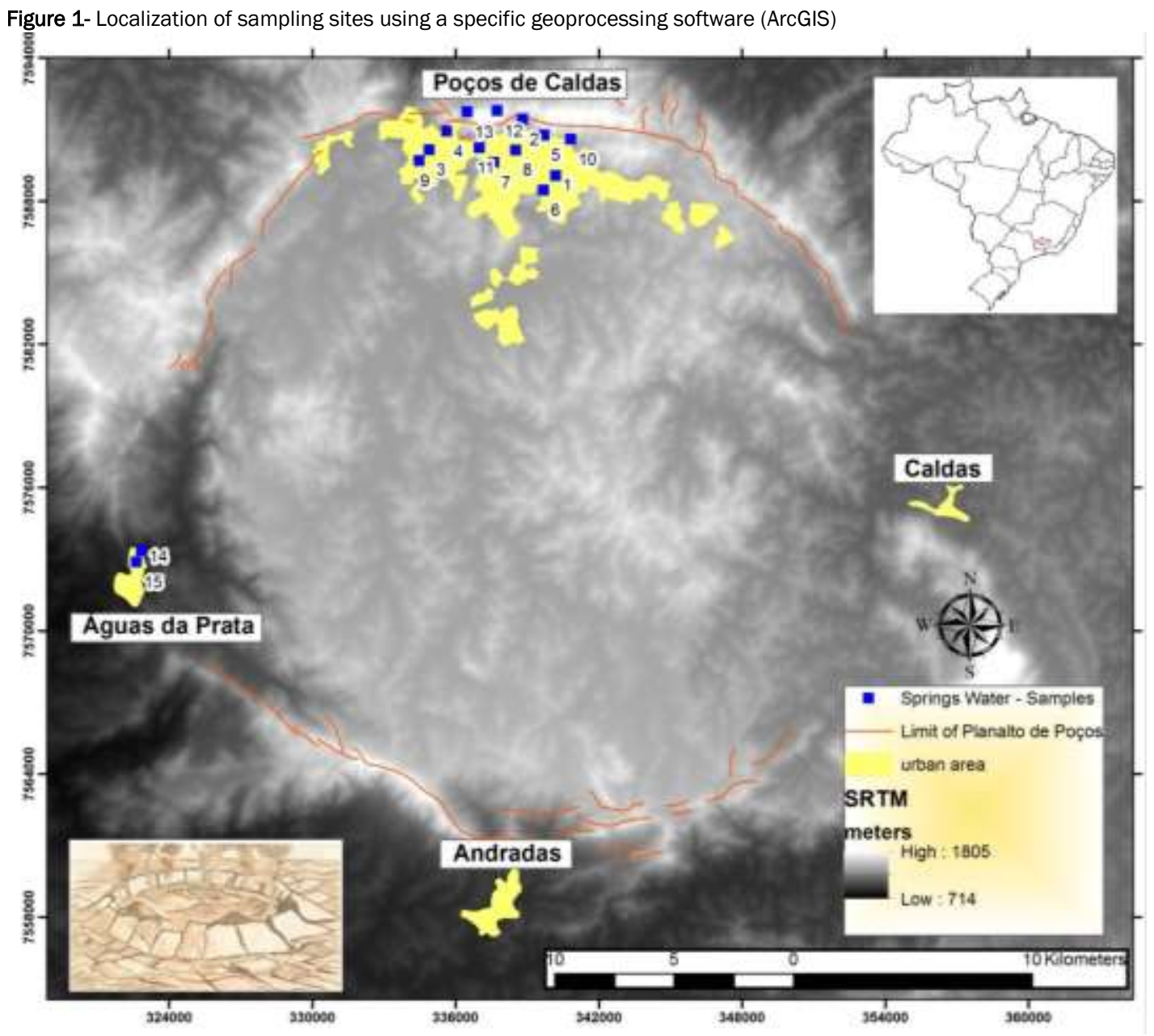


The samples was analyzed by the AlphaGUARD radon detector, were collected in test tubes and coupled to the external accessories (AquaKit and AlphaPUMP). The accessories are supports that performs the removal of radon from groundwater and at the same time puts it in circulation closed by the ionization chamber of the equipment, allowing the measurement of the radioactive element. The analyzes with this equipment were performed at the time of sampling at the sites, were adjusted in a flow of 0,5 L.min ${ }^{-1}$, in an approximate time of 20 minutes.

For the Liquid Scintillation Counting, a syringe was used to collect water samples straight from the sampling site, performed simultaneously the sampling of AlphaGUARD. The water collected was placed directly into a glass vial already filled up with a scintillation cocktail, a solution called 'Ultima Gold $A B$ ', to preserve and retain the radon until it reaches the laboratory (DIAS \& TADDEI, 2009).

\subsection{Measurement Technique Using AlphaGUARD}

Water samples were analyzed using the portable equipment AI phaGUARD, model PQ 2000 and brand Genitron Instruments $\mathrm{GmbH}$, a solid state detector composed by an ionization chamber and an ionization pulse, which measures radon concentration in different matrices, for example in air, soil and building materials. A equipment that verifies the concentration of radon in the range of $2-2 \times 10^{6}$ Bq.L-1 (MAFRA, 2011).

The AlphaGUARD need external accessories for analyze water, the AlphaPUMP and AquaKit. A equipment AlphaPUMP is a bomb that pumps gas into the ionization chamber. The AquaKit used to measure radon in solutions, contains a foam support, safety filter, devaporizing tube $(100 \mathrm{~mL})$, security tube $(100 \mathrm{~mL})$, plastic syringe and hoses. Due to glass-fibre filters coupled with this equipment, other materials that may contain the radon decay products, such as dust, cannot penetrate in it (GENITRON, 2007).

The assembled analysis system is observed on Figure- 2 .

Figure 2 - AlphaGUARD, AlphaPUMP and AquaKit used for radon analysis in spring water

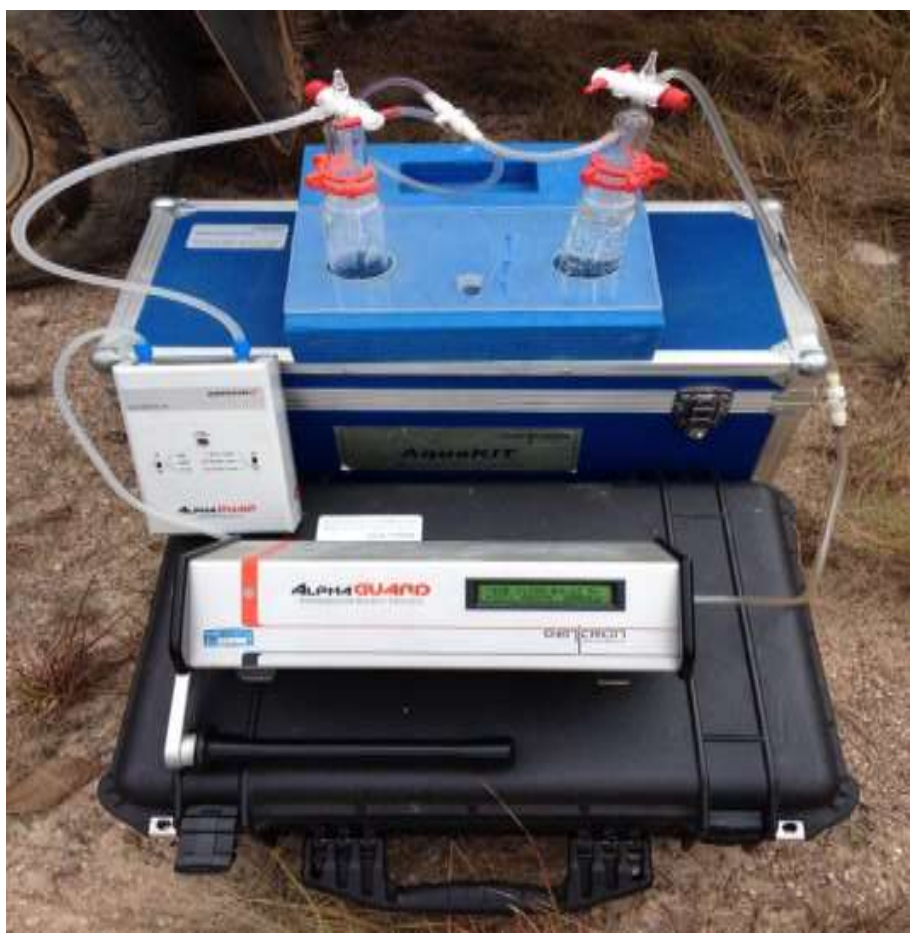

In this method two equations were used to calculate the ${ }^{222} \mathrm{Rn}$ activity concentration in the waters. Equation-1 was used for calculating the concentration of ${ }^{222} \mathrm{Rn}$ in the water (Bq.L-1).

$C_{\text {Water }}=\frac{C_{\text {Air }}\left(\left(\frac{V_{\text {System }}-V_{\text {Sample }}}{V_{\text {Sample }}}+K\right)-C_{0} \cdot\left(\frac{V_{\text {System }}-V_{\text {Sample }}}{V_{\text {Sample }}}\right)\right)}{1000}$

Where $\left(\mathrm{C}_{\text {Air }}\right)$ is the radon concentration in air from the system after the release of ${ }^{222} \mathrm{Rn}$ in the water, $\left(\mathrm{C}_{0}\right)$ is the radon concentration at the beginning of the measurements, $\left(V_{\text {system }}\right)$ is the total volume of the system, in $\mathrm{mL}$, ( $\left.\mathrm{V}_{\text {Sample }}\right)$ is the volume of the water sample and $(K)$ is the partition coefficient of ${ }^{222} \mathrm{Rn}$ (GENITRON, 2007).
The Equation-2 was used for correcting the ${ }^{222} \mathrm{Rn}$ activity concentration considering the decay occurred between the sampling and analysis.

$$
C_{0}=\frac{\mathrm{C}(t)}{e^{-\lambda t}}
$$

Where $(\mathrm{C}(\mathrm{t}))$ is the activity concentration $\left(\mathrm{Bq} \cdot \mathrm{L}^{-1}\right)$ in the period $(\mathrm{t})$ after sampling and $(\lambda)$ is the decay constant of ${ }^{222 R n ~(G E N I T R O N, ~}$ 2007). 


\subsection{Sample and Standard Preparation for Liquid Scintillation Counting (LSC) Measurement}

The LSC method uses the scintillation cocktail, a solution called 'Ultima Gold AB'. This cocktail is a scintillator material produced by dissolving an organic scintillator in an appropriate solvent, which is also widely applied to count radioactive material that can be dissolved as part of the scintillator solution. In this case all radiation emitted by the source immediately passes through a portion of the scintillator and the counting efficiency can nearly reach $100 \%$. This approach, sometimes called internal source liquid scintillation counting, involves dissolving the sample to be counted directly in the liquid scintillator. In this condition, problems relating to sample self-absorption, attenuation of particles by detector windows, and beta backscattering from the detector are avoided (DIAS \& TADDEI, 2009). The equipment Liquid Scintillation Analyzer, model TRI-CARB 2700 TR and brand Canberra PACKARD, used in the spring water analysis by LSC.

The Equation-3 was used to determine the ${ }^{222} \mathrm{Rn}$ activity concentration in the water samples:

$$
A_{222_{R n}}=\frac{N-B}{60 * \varepsilon_{\mathrm{Rn}} * e^{-\lambda \mathrm{t}}}
$$

Where: $A_{222_{R n}}=$ concentration of $222 \mathrm{Rn} ; \mathrm{N}=$ sample counting rate (counting per minute - CPM); $\mathrm{B}=$ background counting rate (deionized water); $\varepsilon_{\mathrm{Rn}}=\mathrm{Rn}$ standard efficiency calculated using ${ }^{226} \mathrm{Ra}$ and ${ }^{241} \mathrm{Am}$ standards; $\lambda=\mathrm{Rn}$ decay constant (seconds) which is $0.693 / \mathrm{t}_{1 / 2} ;\left({ }^{222} \mathrm{Rn}_{1 / 2}=3.8\right.$ days $)$ and $\mathrm{t}=$ time interval between collection and counting (seconds) (SAMPA, 1979).

In order to determine the alpha efficiency, $10 \mathrm{~mL}$ of ${ }^{241} \mathrm{Am}$ standard solution (with an approximate activity of $70 \mathrm{~Bq}$ ) were mixed with $10 \mathrm{~mL}$ of the scintillation cocktail, this cocktail is a solution called 'Ultima Gold AB'. The solution obtained was well mixed and counted using a 0 to $19 \mathrm{Kev}$ range. Sample measurements were done in duplicate. The samples were analyzed four hours after collection and counted for 30 minutes (SAMPA, 1979).

The alpha efficiency $\left(\varepsilon_{\alpha}\right)$ was calculated as in which a background count is subtracted from the standard count, exemplified in Equation-4.

$$
\varepsilon_{\alpha}=\frac{C P M}{A}
$$

In order to determine beta efficiency $\left(\varepsilon_{\beta}\right), 10 \mathrm{~mL}$ of ${ }^{226} \mathrm{Ra}$ standard solution (with an approximate activity of $2 \mathrm{~Bq}$ ) were mixed with $10 \mathrm{~mL}$ of scintillation cocktail. The solution obtained was well mixed and analyzed after 20 days, time in which secular equilibrium occurs. For each ${ }^{222} \mathrm{Rn}$ atom that disintegrates, there are three alpha particles and two beta particles. In addition, for each ${ }^{226} \mathrm{Ra}$ atom that disintegrates, there are five alpha particles and four beta particles.

$\mathrm{N}$ is the total counting (subtracting background counting):

$$
\mathrm{N}=\mathrm{A} * P_{\alpha} \varepsilon_{\alpha}+\mathrm{A} * P_{\beta} \varepsilon_{\beta}
$$

Where: $A=$ added standard activity; $P_{\alpha}$ and $P_{\beta}=$ number of alpha and beta particles emitted by the element; $\varepsilon_{\beta}=$ beta efficiency (counting/disintegration), determined with ${ }^{226} \mathrm{Ra} ; \varepsilon_{\alpha}=$ alpha efficiency (counting/disintegration), determined by the ${ }^{241} \mathrm{Am}$ activity. Therefore:

$$
\varepsilon_{\beta}=\frac{1}{P_{\beta}\left(\frac{N}{A}-P_{\alpha} \varepsilon_{\alpha}\right)}
$$

The calculated ${ }^{222} \mathrm{Rn}$ efficiency will be:

$$
\varepsilon_{222_{R n}}=P_{\alpha} \varepsilon_{\alpha}+P_{\beta} \varepsilon_{\beta}
$$

Considering $P_{\alpha}=3$ and $P_{\beta}=2$ (SAMPA, 1979), then:

$$
\varepsilon_{222_{R n}}=3 * \varepsilon_{\alpha}+2 * \varepsilon_{\beta}
$$

\section{RESULTS AND DISCUSSION}

Samplings at the springs waters of the Poços de Caldas Plateau provided relevant data on the concentration of radon in these groundwater. The results of ${ }^{222} \mathrm{Rn}$ concentrations found through the AlphaGUARD method and LSC method are described in Table1.

Figure-3 shows the results obtained through the AlphaGUARD, demonstrating that $73.3 \%$ of the samples exhibited ${ }^{222} \mathrm{Rn}$ activity concentrations below 150 Bq.L-1, while $13.3 \%$ of samples exhibited concentrations in the range of $150-250$ Bq.L-1. 


\begin{tabular}{|c|c|c|}
\hline Sampling Site & $\begin{array}{l}\text { AlphaGUARD Method } \\
\left.\text { 222Rn (Bq. } \mathrm{L}^{-1}\right)\end{array}$ & $\begin{array}{l}\text { LSC Method } \\
{ }^{222} \mathrm{Rn}\left(\mathrm{Bq} \cdot \mathrm{L}^{-1}\right)\end{array}$ \\
\hline 1- Monjolinho Spring & 88,4 & 82,1 \\
\hline 2- Cristo Spring & 10,4 & 4,9 \\
\hline 3- Quatis 1 Spring & 140,7 & 115,3 \\
\hline 4- Quatis 2 Spring & 155,2 & 120,3 \\
\hline 5- Sebastiao Trindade Spring & 114,8 & 108,2 \\
\hline 6- Sinhazinha Spring & 215,7 & 191,1 \\
\hline 7- Dona Amélia Spring & 145,1 & 124,1 \\
\hline 8- Mário Mourão Spring & 21,6 & 20,8 \\
\hline 9- José F. Silva Spring & 27,4 & 19,0 \\
\hline 10- Santana Spring & 177,8 & 143,8 \\
\hline 11-Thermas Pedro Botelho Spring & 56,4 & 15,3 \\
\hline 12- Amores Spring I & 35,7 & 13,3 \\
\hline 13- Amores Spring II & 270,4 & 228,2 \\
\hline 14- Padre Spring & 108,8 & 1,3 \\
\hline 15- Vilela Spring & 657,2 & 513,2 \\
\hline Average (Bq. $\left.\mathrm{L}^{-1}\right)$ & 148,4 & 113,4 \\
\hline Standard Deviation (Bq.L-1) & 159,6 & 131,6 \\
\hline Maximum (Bq.L-1) & 657,2 & 513,2 \\
\hline Minimum (Bq. $\left.\mathrm{L}^{-1}\right)$ & 10,4 & 1,3 \\
\hline$<150$ Bq.L-1 $(\%)$ & $73,3 \%$ & $80,0 \%$ \\
\hline
\end{tabular}

Figure 3 - ${ }^{222} \mathrm{Rn}$ concentration classes for AlphaGUARD Method (in Bq. $\mathrm{L}^{-1}$ )

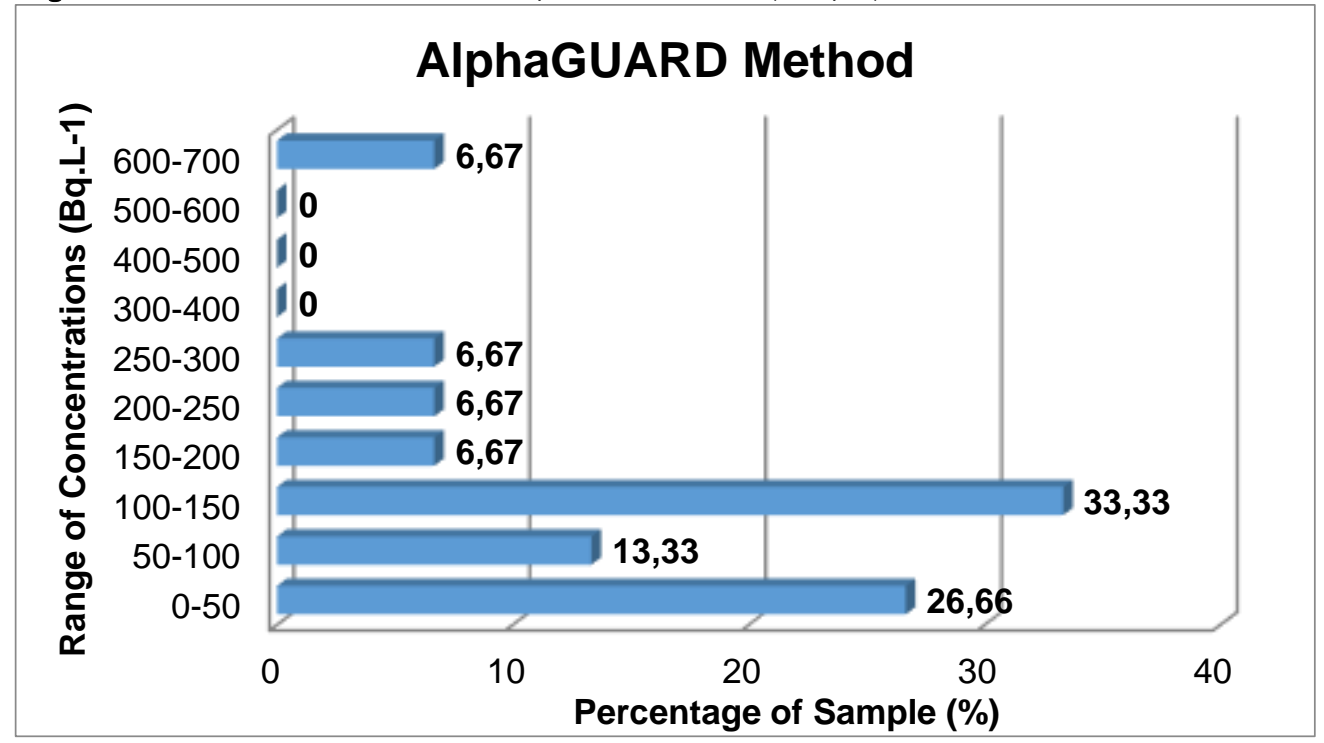

Figure- 4 shows the results of the LSC method and demonstrates that $80 \%$ of the samples presented ${ }^{222} \mathrm{Rn}$ activity concentrations below 150 Bq.L-1, while $13.3 \%$ of the samples presented concentrations in the range of $150-250$ Bq.L-1. 


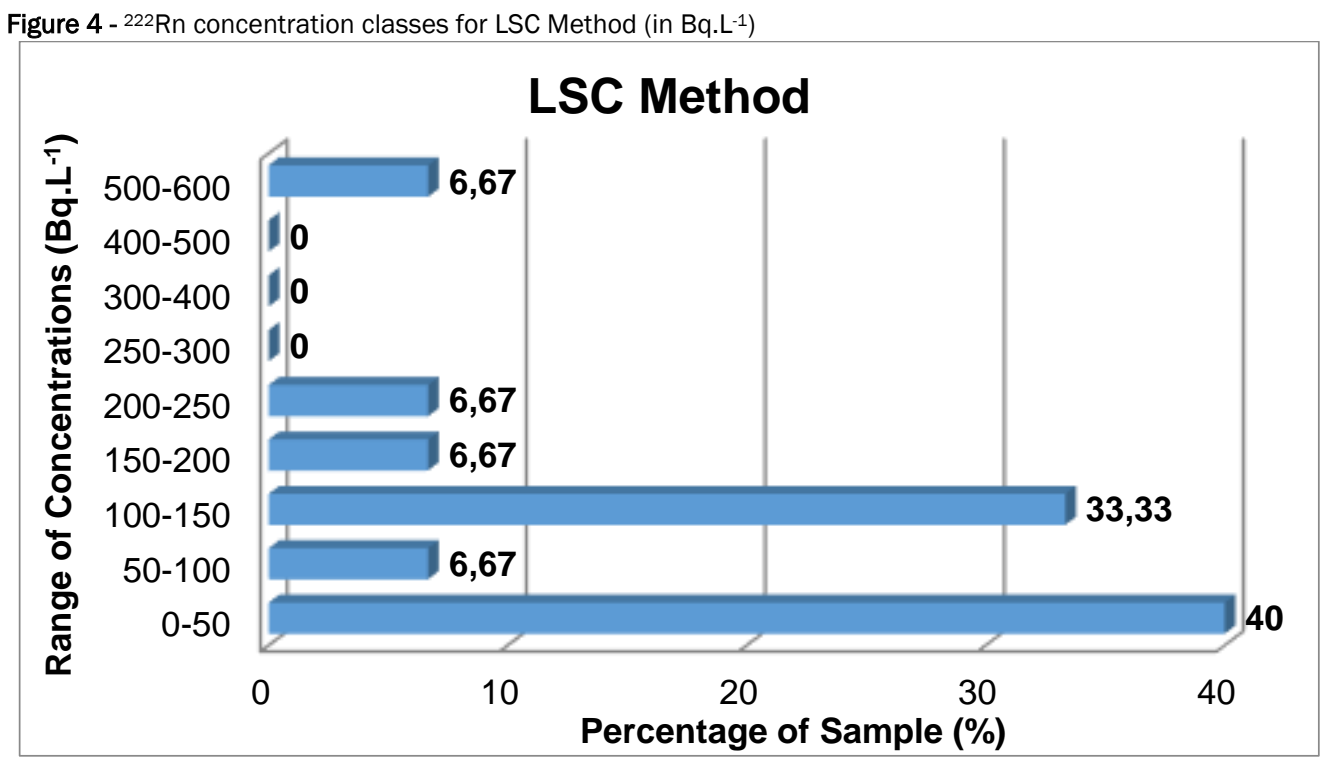

The results found for both techniques applied to analyze the concentration of ${ }^{222} \mathrm{Rn}$ in drinking water samples show variations considered low. It was noted that the values found through the LSC method are slightly lower than the ones obtained using the AlphaGUARD method, with a difference between the methods from $17 \%$ to $20 \%$.

Both radioanalytical techniques present advantages, the LSC method for example, provides a simple sampling procedure and requires lower water volumes. In addition, the Liquid Scintillation Analyzer it features automatic sample exchangers, allowing measurement of many samples in a short period of time (DESIDERI et al., 2005). On the other hand, the AlphaGUARD method allows the measurement of the concentration of ${ }^{222} \mathrm{Rn}$ in the site in an effective and fast way in several matrices (water, soil and rocks) without loss of radon, does not need preparation of solutions for preservation of sample, assembly of the circuit analysis in water is simple and the analysis in the proper place. However, AlphaGUARD requires ancillary components, so that it is impossible to count more than one sample at a time.

The different concentrations of radon found in spring waters reflect the variability of the lithology of the Poços de Caldas Plateau. Of these, $53 \%$ of the sources have concentrations that exceed the maximum level of 100 Bq.L-1 established by the World Health Organization (WHO), reaching up to 657 Bq.L-1.

In relation to Law No. 7,841 Mineral Water Code of Brazil, determined concentrations of radon allow to distinguish the springs waters. According to the code, $36 \%$ of the springs evaluated do not present significant radioactivity, $28 \%$ are classified as weakly radioactive and the rest (above 135 Bq. $\mathrm{L}^{-1}$ ) as radioactive.

It is suggested the mitigation of the sources of water where the concentration of Radon is above the established norms. The most common and used measures are the use of an aeration device or a granular activated carbon filter (GAC). The GAC has a lower cost compared to the aeration method, however the problem is the manipulation, collection and storage of this filter, since it is a material that will absorb the radon and therefore maintain its radioactive emission (US EPA, 1999).
Epidemiological studies have clearly shown that long-term exposure to high radon concentrations in indoor air increases the risk of lung cancer (WHO, 2009). It is known radon in-gested in drinking-water will give a radiation dose to the lining of the stomach. However scientific studies have not shown a definitive link between consumption of drinking-water containing radon and an increased risk of stomach cancer (YE et al., 1998; AUVINEN et al., 2005; WHO, 2009).

Cipriani (2002) mentioned that the dosage limits established

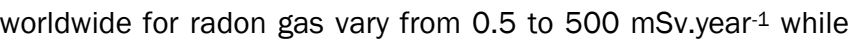
the normal values measured within residences range from 1 to 4 mSv.year ${ }^{-1}$. Other epidemiological study show that the risk associated with the ingestion of water containing radon is limited, the daily intake of a liter of water containing $100 \mathrm{~Bq} . \mathrm{L}^{-1}$ should inflict a dose of only 0.3 mSv.year-1 (DESIDERI et al., 2005). The maximum concentration found in Poços de Caldas city was lower than 270 Bq.L-1, which would be a maximum personal dose of $0.8 \mathrm{mSv}$.year-1, $^{-1}$ and the highest concentration found in the spring waters in Águas da Prata city was 657.1 Bq.L-1, which would be a personal dose of no more than 1.97 mSv.year-1.

\section{CONCLUSIONS}

In this study is possible to observe a very large variation in the radon concentration in waters springs, this variation can occur due to the differences in the characteristics of the rocks through which underground water percolate, such as concentration of ${ }^{226} \mathrm{Ra}$, granulometry, compaction and contact time (SILVA, 2014).

It can be concluded that the concentration values obtained for the water samples collected in the Plateau region's springs are not dangerous for the local population. The risk associated with ingestion of water containing a small concentration of radon is despicable, as it has been reported in other studies (BONOTTO \& LIMA,1997; DIAS \&TADDEI, 2009; VEIGA, 2003).

The relatively high level of radon registration in some the springs waters of the Poços de Caldas Plateau shows the need for continuous monitoring and attention of the health authority and those responsible for the distribution of water to public water supply. It is recommended to deepen the studies, especially in the 
springs waters used for human consumption, with more quantity and all seasonal sampling, in order to identify the variability and concentration of the aquifer.

\section{ACKNOWLEDGEMENTS}

The authors are thankful to the technicians and researchers from Laboratório de Poços de Caldas (LAPOC), unity of Comissão Nacional de Energia Nuclear (CNEN), and to the Fundação PATRIA for financial support.

\section{REFERENCES}

AUVINEN, A. et al. Radon and other natural radionuclides in drinking water and risks of stomach cancer: A case-cohort study in Finland. International Journal of Cancer, v. 10, p. 109-113, 2005.

BONOTTO, L. J. N. \& LIMA, D. M. (1997). 'Transferência de Radônio-222 Das Rochas Do Planalto de Poços de Caldas Para as Águas'. Revista Brasileira de Geociências, v. 27, p. 189-198, 1997.

BURNETT, W. C. \& DULAIOVA, H. Estimating the dynamics of groundwater input into the coastal zone via continuous radon-222 measurements. Journal of Environmental Radioactivity, v. 69, p. 21-35, 2003.

BUSHONG, S. C. Radiologic science for technologists: physics, biology and protection. 7. ed. Mosby, Elsevier, 20011.

CIPRIANI, M. Mitigação dos impactos sociais e ambientais decorrentes do fechamento definitivo de minas de urânio. 363 p. Tese (Doutorado)Universidade Estadual de Campinas, UNICAMP, 2002.

DESIDERI, D.; ROSELLI, C.; RONGONI, A.; SAETTA, D. Rn-222 Determination in Drinkable Waters of aCentral Eastern Italian Area: Comparison Between Liquid Scintillation and Gamma Spectrometry. Journal of Radioanalytical and Nuclear Chemistry, v. 266, n. 2, p. 191197, 2005.

DIAS, F.F. \& TADDEI, M.H.T. Rn-222 Determination in Drinking Water Samples in a Region with Elevated Natural Radioactivity in Brazil: Comparison Between Liquid Scintillation Counting and Gamma Spectrometry. Scientific Communication. Terrae, v. 6, p. 72-76, 2009.
GENITRON - Insturments, AlphaGUARD. The reference in professional radon measurement. Germany. 2007.

IBRAHIMI, Z. F.; HOWARTH, C. B.; MILES, J. C. H. Sources of error in etched-track radon measurements and a review of passive detectors using results from a series of radon intercomparisons. Radiation Measurements, United Kingdom, n. 44, p.750-754, 2009.

MAFRA, K. C. Medidas da Concentração de Radônio-222 em Águas de Poços e Solo da Região do Pinheirinho em Curitiba e Proposta de Mitigação da Água. Dissetação (Mestrado) - Universidade Tecnologia Federal Do Paraná, p. 1-104, 2011.

NIKEZIC, D. \& YU, K. N. Formation and growth of tracks in nuclear track materials. Materials Science and Engineering, Hong Kong, v. 46, p. 51 123, 2004

SAMPA, M. H. O. Estudo e desenvolvimento de métodos analíticos para determinação da radiativiade natural em águas. Dissertação (Mestrado) - Instituto de Energia Atômica- IEA, São Paulo-Brasil. 102 p. 1979.

SILVA, N. C. et al. Towards a Brazilian radon map: consortium radon Brazil. Radiation Protection Dosimetry, v. 160, n. 1-3, p. 226-230, 2014.

THAKKAR, A. Gross alpha measurements in aqueous samples using extraction chromatography and liquid scintillation counting author, 2011.

VEIGA, L. H. S. et al. Preliminary indoor radon risk assessment at the Poços de Caldas Plateau, MG - Brazil. Journal of Environmental Radioactivity, v.70, p.161-173, 2003.

US EPA (United States Environmental Protection Agency), Radon in drinking water health risk reduction and cost analysis. Washington, Federal Register 64, p. 9559-9599, 1999.

WORLD HEALTH ORGANIZATION (WHO), International Radon Project Survey on Radon Guidelines, Programmes and Activities'. Final Report. Geneva, 2007.

WORLD HEALTH ORGANIZATION (WHO), Handbook on indoor radon: a public health perspective. Geneva, World Health Organization. 2009.

YE W. et al. Mortality and cancer incidence in Misasa, Japan, a spa area with elevated radon levels. Japanese Journal of Cancer Research, v. 89 , n. 8, p.789-796, 1998. 